\title{
Összefogás a látás védelmében: körkép a látásromlás prevenciójának hazai és nemzetközi helyzetéről
}

\author{
Kiss Erika ${ }^{1,2,3}$. Pajor Emese dr. ${ }^{1}$ \\ ${ }^{1}$ Eötvös Loránd Tudományegyetem, Bárczi Gusztáv Gyógypedagógiai Kar, \\ Gyógypedagógiai Módszertani és Rehabilitációs Intézet, Budapest \\ ${ }^{2}$ Semmelweis Egyetem, Mentális Egészségtudományok Doktori Iskola, Budapest \\ ${ }^{3}$ Budapesti Korai Fejlesztő Központ, Budapest
}

\begin{abstract}
Az Egészségügyi Világszervezet (WHO) Látásról szóló világjelentése (World report on vision 2019) szerint a népesség növekedése és elöregedése világszerte növekvő számban vezet mérsékelt vagy súlyosabb fokú látáskárosodáshoz. A WHO adatai szerint napjainkban 1,1 milliárd személy él a látáskárosodás valamely formájával, melyek mintegy 80\%-a megelőzhető lenne. A látáskárosodott vagy látáskárosodással veszélyeztetett személyek 90\%-a ugyan alacsony vagy közepes humán fejlettségú országban él, de a rövidlátás és a cukorbetegség miatti retinopathia okozta látáskárosodások száma a magas és a nagyon magas humán fejlettségü országok csoportjában is emelkedik. A WHO előrejelzései szerint ezzel a tendenciával 2050-re 61 millióan élnek majd vaksággal, és 1,7 milliárd személy lehet csökkentlátó világszerte. Riasztó adat, hogy az emberiség 23\%-a rövidlátó, de a jelenlegi növekedési tendenciák alapján 2050-re az előfordulás már 50\%-os lehet. A vakság, illetve a látáskárosodás megelőzése és a látásrehabilitáció fejlődése érdekében a WHO globális akcióprogramjainak (VISION 2020, World report on vision) ismertetésén túl tanulmányunk bemutatja a hazai intézkedéseket és a populációalapú felmérések nemzetközi és hazai eredményeit, köztük a látásromlás legfőbb kórokait és a látáskárosodáshoz leggyakrabban vezető szembetegségeket. Tanulmányunkban bemutatjuk a látáskárosodással élő gyermekek hazai, egészségügyi és pedagógiai szempontból releváns populációjellemzőit is. Összefoglalónk célja felhívni a figyelmet arra, hogy a látáskárosodás megelőzése és a kialakult látáskárosodással élő emberek komplex rehabilitációja nemcsak a szemészeti szakma feladata, hanem be kell, hogy épüljön az egészségügyi alapellátáson túl az oktatási és szociális rendszerekbe is.
\end{abstract}

Orv Hetil. 2021; 162(30): 1187-1197.

Kulcsszavak: látáskárosodás, megelőzés, LÁTÁS 2020, Látásról szóló világjelentés, interdiszciplináris együttmúködés

\section{Joint efforts for saving vision: overview of the prevention of vision loss inside and outside Hungary}

World Health Organization's (WHO) World report on vision (2019) underlines that the increasing size and age of the population leads to a general growth in cases of vision impairment of varying severity (moderate and severe vision impairment). According to WHO data, globally 1.1 billion individuals live with vision impairment, and approximately $80 \%$ of all cases is preventable. While around $90 \%$ of people with vision impairment or at risk of vision impairment live in low- or middle-income countries, the prevalence of near vision impairment and diabetic retinopathy is increasing in high-income countries, too. WHO assumes that if this tendency is not interrupted, by 205061 million individuals will be blind and 1.7 billion individuals will have vision impairment. It is rather frightening that currently $23 \%$ of the world's population is diagnosed with near vision impairment, and with this tendency by 2050 this number may reach $50 \%$. Our study takes a closer look at global actions for preventing vision loss and vision impairment together with the joint efforts to improve vision rehabilitation services, and briefly introduces Hungarian measures, results of international and national population-centred research results, and the major causes of vision impairment. Then, the Hungarian population of children with vision impairment is characterised from both healthcare and pedagogical perspectives. The objective of this review is to point out that the prevention of vision impairment and comprehensive rehabilitation of persons with vision impairment requires joint efforts from ophthalmology, pedagogy and social services.

Keywords: vision impairment, prevention, VISION 2020, World report on vision, interdisciplinary efforts

Kiss E, Pajor E. [Joint efforts for saving vision: overview of the prevention of vision loss inside and outside Hungary]. Orv Hetil. 2021; 162(30): 1187-1197.

(Beérkezett: 2021. január 24.; elfogadva: 2021. február 4.) 


\section{Rövidítések}

$\mathrm{AMD}=$ (age-related macular degeneration $)$ időskori maculadegeneratio; $\mathrm{BNO}=$ Betegségek Nemzetközi Osztályozása; EMMI = Emberi Erőforrások Minisztériuma; GBD Study = (Global Burden of Disease Study) Globális Betegségteher Vizsgálat; IAPB $=$ (International Agency for the Prevention of Blindness) Nemzetközi Vakságmegelőző Intézet; KSH = Központi Statisztikai Hivatal; MÁESZ = Magyarország átfogó egészségvédelmi szúróprogramja; MSVI = (moderate and severe vision impairment) mérsékelt és súlyos fokú látáskárosodás; ROP $=$ (retinopathia prematurorum) koraszülöttek ideghártya-károsodása; SNI = sajátos nevelési igény; VLEG = (Vision Loss Expert Group) Látásvesztés Szakértői Csoport; WHO = (World Health Organization) Egészségügyi Világszervezet

A vakság és a csökkent látás világszerte jelentős közegészségügyi probléma $[1,2]$. A látáskárosodás egyéni megélése sok különböző tényezőtő́l függ. Idetartozik többek között a megelőzés és a beavatkozó kezelések hozzáférhetősége, a látási rehabilitáció (ideértve a szemüvegeket, fehér botokat is) elérhetősége és a megélt akadályozottság a közlekedés, a tájékozódás, a mindennapi élet, az ügyintézés, az információkhoz való hozzáférés terén [3]. A látásromlás több szempontból is negatívan befolyásolja az érintett személyek életét. Nehezíti az önellátáshoz szükséges mindennapos tevékenységek elvégzését, csökkenti az önállóságot, rontja az életminőséget, és megrövidítheti a várható élettartamot $[4,5]$.

A vakság és a csökkent látás világszintú előfordulására vonatkozó első megbízható adatok 1993-ban jelentek meg WHO Global Database on Blindness and Visual Impairment (WHO Globális adatbázis a vakságról és a látáskárosodásról) címen, mely a Világbank számára hivatalos kiindulópontot jelentett a globális megelöző programok finanszírozásához. A vak személyek becsült száma a világon 1993-ban megközelítően 38 millió, a csökkentlátóké majdnem 110 millió volt [6]. Jelenleg 1,1 milliárd látáskárosodott személyt tart számon a WHO, akik közül 43 millióan élnek vaksággal. Bár a vakok és a csökkentlátók nagy része fejlődő országokban él, a szembetegségek okozta látáskárosodás Európában és hazánkban is fontos egészségügyi probléma [2]. A látásromlás és a vakság megelőzésére a WHO és az IAPB 1999-ben indította el világméretű VISION 2020 programját, amelynek stratégiai fejlesztései csak névleg fejeződtek be az elmúlt esztendőben. Új fókuszpontokkal, a növekvő globális népességgel szembenézve tovább folytatódnak a vakság és a csökkent látás felszámolására tett lépések a WHO World report on vision (Látásról szóló világjelentés, WRV) keretében. A VISION 2020 programban több globális kutatás (Vision Loss Expert Group [VLEG]; Global Burden of Disease Study [GBD]) is célul tűzte ki az érintett populáció számának és összetételének felmérését a prevenció és a rehabilitáció regionális stratégiai tervezéséhez. Az epidemiológiai felmérések a látáskárosodás mértékét jellemzően az 1 . táblázatban bemutatott osztályozás szerint, a látóélesség alapján ha-
1. táblázat

A látáskárosodás nemzetközi meghatározása és klasszifikációja (BNO-11) [7]

\begin{tabular}{|c|c|c|}
\hline & \multicolumn{2}{|c|}{ Látóélesség a jobban múködő szemen } \\
\hline & Rosszabb mint: & $\begin{array}{c}\text { Egyenlő vagy jobb } \\
\text { mint: }\end{array}$ \\
\hline \multicolumn{3}{|c|}{ I. Távolilátás-károsodás (Distance presenting vision impairment) } \\
\hline I.1. Enyhe fokú (Mild VI) & $6 / 12(V=0,50)$ & $6 / 18(\mathrm{~V}=0,33)$ \\
\hline $\begin{array}{l}\text { I.2. Mérsékelt fokú } \\
\text { (Moderate VI) }\end{array}$ & $6 / 18(V=0,33)$ & $6 / 60(\mathrm{~V}=0,10)$ \\
\hline I.3. Súlyos fokú (Severe VI) & $6 / 60(\mathrm{~V}=0,10)$ & $3 / 60(\mathrm{~V}=0,05)$ \\
\hline I.4.Vakság (Blindness) & $3 / 60(V=0,05)$ & \\
\hline $\begin{array}{l}\text { II. Közelilátás-károsodás } \\
\text { (Near presenting vision } \\
\text { impairment) }\end{array}$ & \multicolumn{2}{|c|}{$\begin{array}{l}\text { maximális korrekcióval } \mathrm{V}=0,5 \\
\text { vagy rosszabb } \\
\text { (N6 = a nyomdai 6-os méretű } \\
\text { betútípust nem tudja elolvasni } \\
40 \mathrm{~cm} \text {-ről) }\end{array}$} \\
\hline
\end{tabular}

BNO = Betegségek Nemzetközi Osztályozása; VI = látáskárosodás

tározzák meg, de kitérnek a látótér szúküulésének mértékére is: látáskárosodott az a személy is, akinek centrális látótere legfeljebb $20^{\circ}$. A BNO-11 meghatározása alapján [7] megkülönböztetünk távoli- és közelilátás-károsodást. Hazánkban a közeli látóélesség megállapításához a Csapody-féle táblázatot használják a látásvizsgálatok során, a nemzetköziben alkalmazott nyomdai betúnagyságokkal szemben.

\section{A látáskárosodás előfordulási gyakorisága és fő kórokai}

A VLEG és a GBD idei (2021) online publikált összefoglaló tanulmánya [8] differenciáltan adja közre a távoli- és közelilátás-teljesítményük tekintetében látáskárosodottá vált személyek számát (2. táblázat). A táblázatban feltüntettük az egyes súlyossági fokokhoz tartozó személyek számát, ezen belül külön oszlopban megjelenítve az érintett gyermekek számát.

Előrejelzéseik szerint (1. ábra) ezzel a tendenciával 2050-re 61 millióan élnek majd vaksággal, és 1,7 milliárd személy lehet csökkentlátó világszerte $[9,10]$.

2. táblázat |A látáskárosodással élő személyek száma világszerte [8]

\begin{tabular}{llrc}
\hline & & \multicolumn{1}{c}{ Összesen } & Gyermek $(\leq 15$ év $)$ \\
\hline Távoli látásukban & Vak & 43 millió & 2 millió \\
érintettek & MSVI & 295 millió & 30 millió \\
& EVI & 257 millió & 58 millió \\
\hline $\begin{array}{l}\text { Közeli látásukban } \\
\text { érintettek }\end{array}$ & 510 millió & - \\
\hline Összes VI & & \\
\hline
\end{tabular}

EVI = enyhe fokú látáskárosodás; MSVI = mérsékelt és súlyos fokú látáskárosodás; $\mathrm{VI}=$ látáskárosodás 


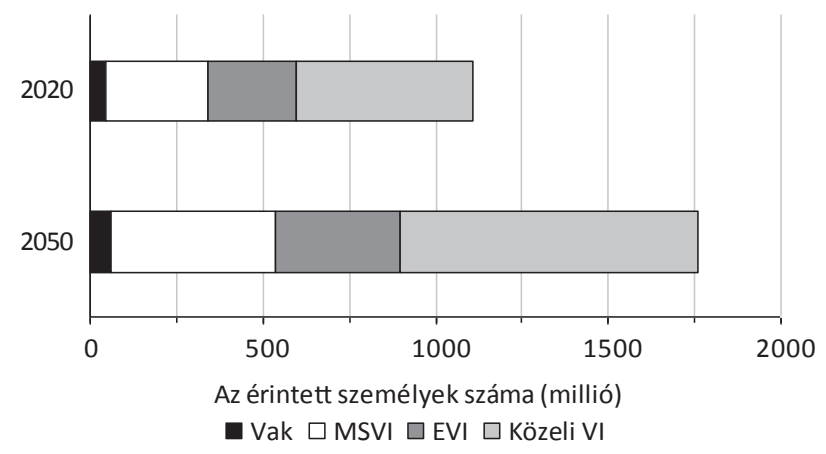

1. ábra

\begin{abstract}
A látáskárosodással élő személyek jelenlegi és 2050-re becsült száma (IAPB Vision Atlas 2020 - VLEG/GBD 2020 modell) [10]

EVI = enyhe fokú látáskárosodás; IABP = Nemzetközi Vakság megelőző Intézet; MSVI = mérsékelt és súlyos fokú látáskárosodás; VI = látáskárosodás; VLEG/GBD = Látásvesztés Szakértői Csoport/Globális Betegségteher Vizsgálat
\end{abstract}

A WHO WRV [1] szerint az idősödő népesség, az életmódváltozás (túl sokat tartózkodunk természetes fény nélküli zárt térben) és a szemorvoslás korlátozott hozzáférése - különösen az alacsony és közepes jövedelmű országokban - a fő oka az egyre növekvő számú látáskárosodásnak.

A látáskárosodás előfordulási gyakoriságának és kórokainak a társadalmi-gazdasági és a geográfiai helyzet szerinti, továbbá a nemek miatti különbözőségei továbbra is fennmaradnak, azaz a látásgyengeséggel élő legtöbb személy Dél- és Kelet Ázsiában, Latin-Amerikában, Afrika nyugati, keleti és középső, valamint a Szaharától délre fekvő részén él. Az alacsony és közepes jövedelmú régiókban a távolilátás-károsodás prevalenciája négyszer nagyobb, mint a magas jövedelmú régiókban $[9,11]$. Míg a nyugat-, kelet- és közép-szaharai régiókban a nem diagnosztizált közelilátás-károsodások száma a látáskárosodások több mint 80\%-áért felelős, addig az észak-amerikai, ausztráliai, nyugat-európai és csendes-óceáni területeken ez az arány kevesebb mint 10\% [12]. A WRV 2019 a látáskárosult személyek látáskárosodásának vezető okait - esetgyakoriságuk sorrendjében - az alábbiak szerint állapítja meg: nem korrigált presbyopia - 826 millió fö; korrigálatlan refrakciós hibák - 123,7 millió fö; szürke hályog - 65,2 millió fö; glaucoma (zöld hályog) - 6,9 millió fó; szaruhártyahomály - 4,2 millió fó; cukorbetegség okozta szemfenéki eltérések - 3 millió fö; trachoma -2 millió fó [1].

\section{Látásromláshoz vezetô szembetegségek}

A WRV 2019 [1] kiemeli a leggyakrabban látásromláshoz vezető szembetegségeket, amelyek kezdeti fázisukban még nem okoznak feltûnő látásgyengeséget, kezeletlenségük és/vagy progrediáló jellegük miatt azonban később csökkentlátóvá válhatnak az érintett személyek. A rövidlátás (myopia) 2,6 milliárd személyt érint minden korosztályból, ebből 277 millió ember él magas fokú rö- vidlátással, és 312 millió személy 19 év alatti [13]. Riasztó adat, hogy az emberiség 23\%-a rövidlátó, de a jelenlegi növekedési tendenciák alapján 2050-re az előfordulás már 50\%-os lehet. A Távol-Keleten jelenleg a fiatalok 90-95\%-a rövidlátó, és ezen belül a látásvesztéssel fenyegető nagyfokú rövidlátóság előfordulása is $1-2 \%$-ról 20\%-ra nőtt [13]. A presbyopiával élő emberek száma a világon 1,8 milliárdra tehetó, akik közül 1 millió rendelkezik korrekcióval [12]. Időskori maculadegeneratióval (AMD) 195,6 millió ember él [14].

Cukorbetegség okozta retinopathiával 146 millió ember él - 2015-ben 18 éves kor felett 422 millió embert érintett a cukorbetegség [15]. Glaucomával 76 millióan élnek (a 40-80 éves korosztályból) [16]. Trachomafertőzés miatti szemfelszín-hegesedéssel 2,5 millió ember él minden korosztályra kiterjedően [1]. A látásgyengeségért felelős szembetegségekkel élők jelentős része az alacsony jövedelmü országokban él. A szembetegségek megjelenési formái szintén régiókhoz köthetók. A szürke hályog például gyakrabban fordul elő az alacsony és a közepes jövedelmú országokban, mint a magas jövedelmưekben. A magas jövedelmű országok esetén azonban a diabeteses retinopathia, a zöld hályog és az AMD a leggyakoribb kórok [17]. A jelentés hangsúlyozza továbbá, hogy a nem korrigált fénytörési hibákból származó csökkent látás négyszer gyakoribb az alacsony és a közepes jövedelmú országokban, mint a magas jövedelmú régiókban. Gyermekek esetén szintén nagy különbség van a régiók között. Míg az alacsony jövedelmú országokban a veleszületett szürke hályog a látáskárosodást okozó szembetegségek vezető kóroka, addig a közepes jövedelmű országok esetén ez a koraszülöttek ideghártya-károsodása (ROP) [9]. A látásromlás előfordulása nagyobb arányú a vidéken élők, az alacsony jövedelmú családok, a nők, az idősek, a fogyatékos személyek, az etnikai kisebbségek és bennszülött lakosság körében [12].

\section{A 'VISION 2020'-tól a 'World report on vision'-ig}

A 'VISION 2020: Right to Sight' (LÁTÁS 2020: Jog a látáshoz) programban világszerte több jelentős lépést sikerült tenni a vakság és a látáskárosodás megelőzéséért és a látásrehabilitáció fejlesztéséért. Országonként, régiónként különböző módokon, különböző eszközökkel igyekeztek megvalósítani a program célkitúzéseit, az adott terület kóroki szempontjainak megfelelően. A VISION 2020 program az első öt évben a kórokozók és a betegségek visszaszorításában a szürke hályog, a trachoma és a folyami vakság megelózésére fókuszált, a cél a gyermekkori vakság, a nem korrigált fénytörési hibák és a csökkent látás számának csökkentése volt. A vakságot okozó vezető fertőzés, a trachoma visszaszorításában nagymértékú eredményt értek el a szakemberek. 2019-re 91\%-kal csökkent a trachomaveszélyeztetett emberek száma [18]. Az 50 ország szolgáltatta adatok szerint a szürkehályog- 
mütétek száma az 1988. évi 5 millióról 2008-ra 15 millióra emelkedett. A mütéten átesett személyek 72\%-ának látásélessége elérte a 0,1 visusnál magasabb értéket, vagyis ők kikerültek a „vakság” kategóriájából [19]. A program egyik kiemelkedő nemzetközi kezdeményezése volt a 2000 óta minden év október második csütörtökén megrendezésre kerülő Látás Világnapja (World Sight Day). Célja, hogy felhívja a figyelmet a vakságra és a csökkent látásra, vagyis a látás megörzése érdekében történő prevenció és a látásrehabilitáció fontosságára.

A jelenlegi Látásról szóló világjelentés nagyobb tudatosságot és fokozott helyi politikai akaratot és befektetéseket szorgalmaz a szemgondozás globális megerősítéséért. Hangsúlyozza, hogy a vakság és a csökkent látás világszerte közegészségügyi probléma. A csökkent látás megelőzése és a kialakult látáskárosodással élő emberek komplex rehabilitációja nemcsak a szemészeti szakma feladata, hanem be kell, hogy épüljön az egészségügyi alapellátáson túl az oktatási és szociális rendszerekbe is. A 2020. évi Látás Világnapjának szlogenje és témája a 'Remény a láthatáron' - 'Hope in Sight' volt, azaz olyan világ lenne ideális, amelyben senki sem veszti el szükségtelenül a látását, és ahol azok, akik elkerülhetetlen látásvesztéssel rendelkeznek, teljes életet élhetnek, és ahol biztosított az általános hozzáférés az átfogó szemészeti és komplex rehabilitációs szolgáltatásokhoz [1]. A program az „integrált, emberközpontú szemkezelés” fontosságát hangsúlyozza, mely biztosítja az egyéni szükségletek szerinti, hosszú távú szemészeti ellátást, és szorgalmazza a szemészeti rehabilitációban részt vevő szakmák együttmúködését [1].

\section{VISION 2020 Magyarországon (2001-2020)}

Magyarországon a Magyar Szemorvostársaság 2001-ben csatlakozott a WHO és az IABP VISION 2020 programjához. A VISION 2020 programban a hazai kormányzat, a szemészeti szakma (a Magyar Szemorvostársaság, a Szemészeti Szakmai Kollégium) mellett a vakok és gyengénlátók oktatását és rehabilitációját végző intézményeknek és szakembereknek is aktív szerep jutott. A program hazai résztvevőinek kiemelt céljuk volt a szakmaközi (interdiszciplináris) együttmúködés megszervezése, amely a látáskárosodás megelőzésére és az érintett látáskárosult személyek hatékony ellátására irányul. A hazai program keretében több alkalommal történt adatgyưjtés a hazai vaksági okok felmérésére [2022]. Magyarországon a felnőtt- és időskorú populáció körében bekövetkező súlyos fokú látásromlás vagy látásvesztés leggyakoribb okai százalékosan: AMD - 22,7\%; diabeteses retinopathia - 15,6\%; rövidlátóság - 13,9\%; zöld hályog 12,6\%; szürke hályog 7,0\%, látóideg-atrophia - 6,4\% [20-22]. Az előfordulási gyakoriságok megegyeznek a Közép-európai régióban előforduló szemészeti kórképek gyakoriságával [23].
Húszéves életkor alatt a leggyakoribb vaksági ok a ROP volt, míg 40 és 60 éves kor között a myopia és a diabeteses retinopathia, 60 év felett az AMD és a diabeteses retinopathia [20-22]. A felmérések eredményeinek tükrében a hazai VISION 2020 mozgalom a koraszülöttek (ROP) telemedicinális szürését és kezelését, valamint a cukorbetegek szemfenéki telemedicinális szürését és kezelését alakította ki $[2,24]$. A VISION 2020 program keretében, a WHO kezdeményezésére, 2001 óta minden év október második csütörtökén hazánkban is megrendezésre kerül a Látás Világnapja, hogy a látásmegórzés (prevenció) és a látásrehabilitáció fontossága a lakosságban, a szakemberekben, valamint a döntéshozókban is tudatosuljon. A Látás Világnapjának rendezvényei egyre szorosabb szakmaközi együttmúködéseket eredményeztek az érintett populációt és érdekvédelmüket ellátó szakemberek (szemészek, gyógypedagógusok, pszichológusok, látásrehabilitációs szakemberek, szociális munkások) körében. Így született meg 2016-ban a Nemzeti Programbizottság a Jó Látásért szervezet, amelyet az Emberi Erőforrások Minisztériuma kezdettől fogva támogat. A Bizottság fó célkitűzése a WHO „Universal Eye Health: Global Action Plan 2014-2019” hazai megvalósításának elősegítése, amely magában foglalja az elkerülhető vakság és csökkent látás megelőzését, a jó látás megőrzését, illetve a látásrehabilitáció elérhetőségének fejlesztését és a vakok és gyengén látó személyek számára a teljes élet lehetőségének biztosítását. (További részletek elérhetők a Bizottság honlapján: [25].) A Bizottság munkájában szemész szakorvosok (Szemészeti Szakmai Kollégium, Magyar Szemorvostársaság), látáskárosodott gyermekeket és felnőtteket ellátó bázisintézmények (Gyengénlátók Általános Iskolája, Egységes Gyógypedagógiai Módszertani Intézménye; Vakok Óvodája, Általános Iskolája, Szakiskolája, Egységes Gyógypedagógiai Módszertani Intézménye; Magyar Vakok és Gyengénlátók Országos Szövetsége) vezetői, gyógypedagógusai és látáskárosultak rehabilitációját végző egyesületek, alapítványok (Siketvakok Országos Egyesülete; Fehér Bot Alapitvány) szakemberei vesznek részt.

Preventív jellegü, lakossági szemészeti szû́rések Magyarország átfogó egészségvédelmi szüröprogramja (MÁESZ 2010-2030) keretében történnek és történtek, amely 2010-ben kezdte meg múködését a Népegészségügyi Prevenció Magyarországon (lásd bóvebben: [26]) program keretében. Egy-egy kiválasztott településen szúrőkamionban és mobil sátrakban zajlanak a lakossági általános szemészeti szűrések, kiegészülve telemedicinális diabeteses retinopathia szûréssel is. A szürésekhez optikusok és látásrehabilitációs szakemberek is csatlakoztak tanácsadói szolgáltatásaikkal, kiadványaikkal. A MÁESZ program szakmai és koordinációs bizottsága 2012 óta évente megrendezi azokat a népegészségügyi konferenciákat, amelyeken a Magyar Szemorvostársaság képviseletében prof. $d r$. Németh János és kollégái rendszeresen beszámolnak a szűrőprogramok keretében elvégzett szemészeti vizsgálatok eredményeiről [2, 22, 24, 26-28]. 
Az országos szúrőprogramok szemészeti vizsgálatain 2011 és 2018 között több mint 123 ezer személy vett részt; a legtöbb vizsgált életkora 26 és 55 év között volt, és magasabb volt a szembetegségek aránya a nők körében [2]. A szűrésen megjelent nők 67\%-a, a férfiak 72\%a szemüveget viselt. A nem megfelelően korrigáló szemüvegek („hibás szemüvegek”) előfordulása 31\% volt [27]. Németh professzor a 2020. évi konferencia-elöadásában kiemelte, hogy a szürőprogram keretében 2014 és 2019 között vizsgált, több mint 80 ezer személy között a rövidlátás 52\%-ban fordult elő. Az adatok szerint a fiatalabb korosztályokban (23-40 évesek között) a rövidlátóság 3,3-szer gyakoribb, mint a 60 évesnél idősebbek között [28]. A szemészeti programmal a Magyar Szemorvostársaság 2014-ben a MÁESZ Szakmai Díját nyerte el, Németh János professzor pedig 2019-ben Kiss István-emlékdijat kapott. A hazai VISION 2020 program mindezek mellett életre hívta a Semmelweis Egyetem Szemészeti Klinikáján múködő Optikai Rehabilitációs Szakrendelést, a Látássérültek Tanácsadó Szolgálatát és egy pontszerző látásrehabilitációs tanfolyamot. A program hazai szakembereinek szerepe volt az Egészségügyi Minisztérium 0-18 éves életkorú gyermekek szemészeti szürốvizsgálatairól szóló szakmai irányelvének [29] kidolgozásában és az Emberi Erôforrások Minisztériuma koraszülöttek retinopathiájának szüréséröl, diagnosztikájáról, kezelésérôl és szemészeti gondozásáról szóló szakmai irányelvének megszületésében [30]. A MÁESZ programban a 2020 és 2030 közötti időszakban kiemelt prioritása lesz a gyermekek prevenciójának: az „Utazás az egészség birodalmába” programsorozatban évi 75000 gyermek ingyenes komplex szürését tüzték ki célul, amelyben gyermekszemészeti vizsgálatok is szerepelnek [31].

\section{A látáskárosodással élő személyek és gyermekek száma Magyarországon}

A hazánkban látáskárosodással élő személyek számának meghatározása előtt tekintsük át a hazai vak és csökkentlátó személyekre alkalmazott leggyakoribb meghatározásokat. A vaksággal vagy a látásgyengeség valamely formájával élő személyekre használt összefoglaló kifejezés eltérő medikális és pedagógiai/szociális/fogyatékosságtudományi értelemben. Orvosi értelemben a látáskárosodás, pedagógiai/szociális értelemben pedig a látássérülés fogalmat használjuk. A jogi szaknyelvben alkalmazott látási fogyatékos/látásfogyatékos kifejezés ekvivalens a fogyatékosságtudományban és (gyógy)pedagógiában elterjedt látássérült fogalommal [32]. Pedagógiai/fogyatékosságtudományi szempontból látássérült az a személy, akinek a két szemén korrekcióval mérhető látóélessége az ép látás $0-0,33 \%$-a (V: 0,33) vagy ennél kisebb, illetve látótérszúkülete nem több 20 foknál [32, 33]. A látássérültek csoportjába tartoznak a vak, a gyengén látó és az alig látó személyek [32], napjaink pedagógiai praxisában azonban az alig látó személyek a látásteljesítményük sze- rint besorolódnak a vak vagy a gyengén látó csoportba [34]. A vak, valamint a látásukat praktikusan kismértékben használó alig látó személyek elsősorban tapintó-halló életmódot folytatnak (Braille-írás - dombornyomásos írás-olvasás tanulás, fehér bot, auditív tájékozódás), látóélességük 0-5\% (V: 0-0,05). A látásukat praktikusan jól használó alig látó és a gyengén látó személyeket pedig a látó-halló életmód (vizuális alapú adaptált írás-olvasás, nagyítás, kontrasztos környezet, jó megvilágítás) jellemzi, látóélességük $0,1-0,33 \%$ [32-34].

A hazánkban látáskárosodással élő személyek számának átfogó meghatározásához a Központi Statisztikai Hivatal (KSH) reprezentatívnak tekintett cenzus- és mikrocenzusadatait használtuk fel. Egyrészt a látáskárosodott személyek (látássérültek) egyes időszakokban és azonos kategóriákban (vak és gyengén látó) rögzített elemszámainak, előfordulási gyakoriságainak összehasonlítása végett, másrészt mert nyilvánosan elérhető, publikált módszertani anyagokkal a KSH rendelkezik, amelyekból tájékozódhatunk a mintavételi eljárásokról, módszertanokról [23, 35-38]. A látáskárosodással élő személyek számát Magyarországon - az 1990 és 2011 közötti három népszámlálás (Népszámlálás 1990, 2001, 2011) $[36,37,39]$ és a legutóbbi mikrocenzus (Mikrocenzus 2016) [23] Fogyatékossággal élö személyek és Fogyatékossággal élők korcsoport és fogyatékosságtípus adattáblái alapján összesítettük (3. táblázat), külön feltüntetve a gyengén látó és vak csoportok ifjabb (0-14 év közötti) és idősebb (75 év fölötti) korosztályának számszerű jellemzőit [23].

A népszámlálási időszakokban rögzített adatokból jól látszik az a tendencia, hogy a csökkenő népességszám ellenére a látáskárosodott személyek összlétszáma növekszik hazánkban, különösen az idősebb korosztályban.

\begin{tabular}{l|l} 
3. táblázat & $\begin{array}{l}\text { A vak és a gyengén látó személyek összesített száma a teljes né- } \\
\text { pességben, korosztályos szélsőértékekkel: gyermek: } 0-14 \text { év, idós: } \\
75 \text { év feletti }[23]\end{array}$
\end{tabular}

\begin{tabular}{|c|c|c|c|c|c|c|}
\hline & $\begin{array}{c}\text { Össz- } \\
\text { népesség }\end{array}$ & $\begin{array}{l}\text { Látás- } \\
\text { sérült }\end{array}$ & \multicolumn{2}{|c|}{ Gyengén látó } & \multicolumn{2}{|c|}{ Vak } \\
\hline \multirow{3}{*}{$\begin{array}{l}\text { Népszám- } \\
\text { lálás, } 1990\end{array}$} & \multirow[t]{3}{*}{10374823} & \multirow[t]{3}{*}{51400} & \multicolumn{2}{|c|}{43616} & \multicolumn{2}{|c|}{7785} \\
\hline & & & gyermek & $i d o ̂ s$ & gyermek & $i d{ }^{\prime \prime} s$ \\
\hline & & & 3115 & 8845 & 1020 & 2425 \\
\hline \multirow{3}{*}{$\begin{array}{l}\text { Népszám- } \\
\text { lálás, } 2001\end{array}$} & \multirow[t]{3}{*}{10198315} & \multirow[t]{3}{*}{64558} & \multicolumn{2}{|c|}{55115} & \multicolumn{2}{|c|}{9443} \\
\hline & & & gyermek & $i d o s$ & gyermek & $i d o s$ \\
\hline & & & 2731 & 13423 & 334 & 3300 \\
\hline \multirow{3}{*}{$\begin{array}{l}\text { Népszám- } \\
\text { lálás, } 2011\end{array}$} & \multirow[t]{3}{*}{9937628} & \multirow[t]{3}{*}{82484} & \multicolumn{2}{|c|}{73430} & \multicolumn{2}{|c|}{9054} \\
\hline & & & gyermek & idós & gyermek & $i d{ }^{\prime \prime} s$ \\
\hline & & & 2344 & 23944 & 247 & 2886 \\
\hline \multirow{3}{*}{$\begin{array}{l}\text { Mikrocen- } \\
\text { zus, } 2016\end{array}$} & \multirow[t]{3}{*}{9803837} & \multirow[t]{3}{*}{69747} & \multicolumn{2}{|c|}{61819} & \multicolumn{2}{|c|}{7928} \\
\hline & & & gyermek & idós & gyermek & $i d o$ s \\
\hline & & & 1802 & 21457 & 335 & 2179 \\
\hline
\end{tabular}

$\mathrm{KSH}=$ Központi Statisztikai Hivatal 

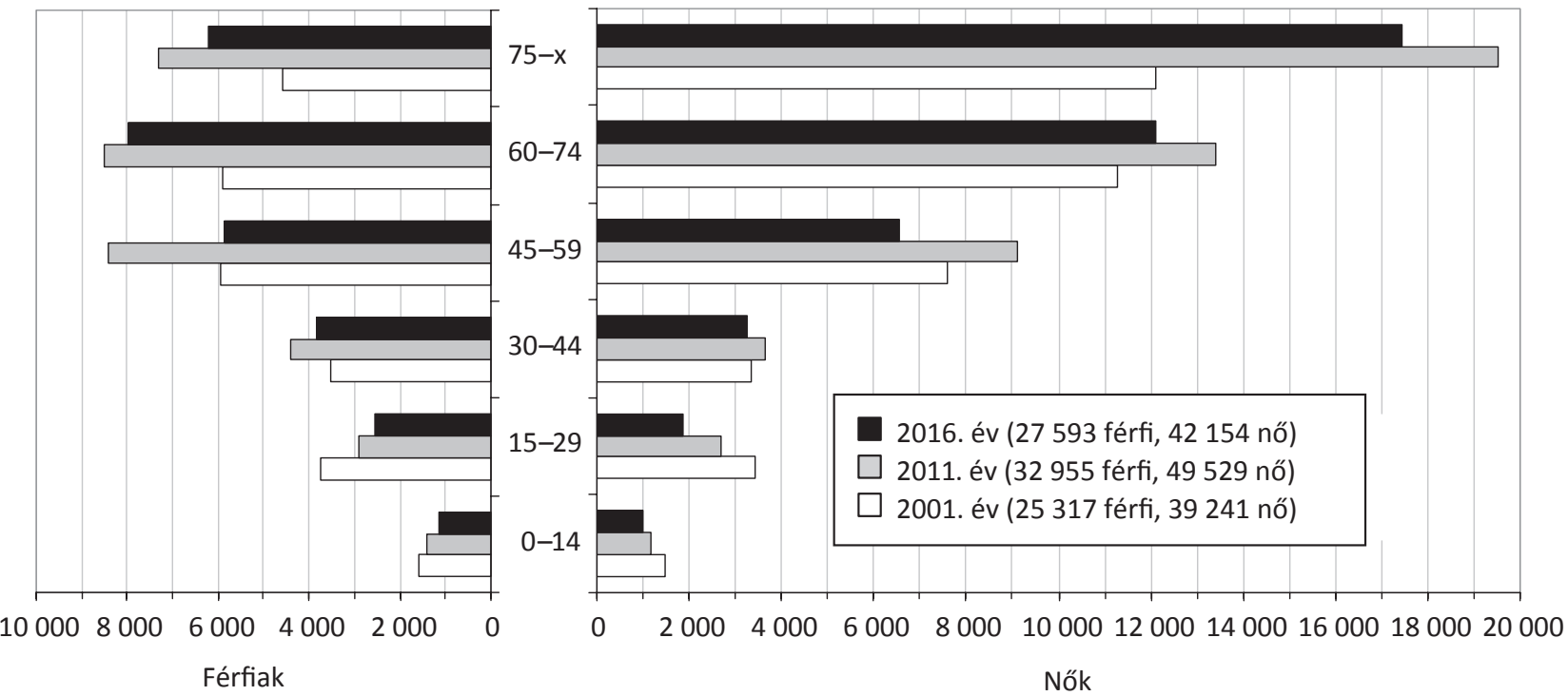

2. ábra

| A látáskárosodással élő személyek hazai koreloszlása (KSH 2001, 2011, 2016) [37-39]

$\mathrm{KSH}=$ Központi Statisztikai Hivatal

A 75 év feletti látássérültek a 2010 utáni években tízszer többen vannak, mint a 14 év alatti érintett gyermekek. A mikrocenzus adatai visszaesést mutatnak ugyan a gyengénlátók körében, ami adódhat abból, hogy az adatfelvétel 10\%-os populációs mintán történt, így az ebből származó adatok ugyan magas megbízhatóságú becslésnek tekinthetők, de a kisebb elemszámú populációknál, mint amilyen a látássérült gyermekek csoportja, a becslések jóságának megbízhatósági szintje csökken. A népszámlálási adattáblákból kirajzolódik (2. ábra), hogy a látáskárosodással élő legtöbb személy 45 év feletti. 45 éves kor alatt a férfiak, 45 éves kor felett pedig a nók száma magasabb az érintett populációban [37-39].

A nemzetközi osztályozásban a mérsékelt és súlyos fokú látáskárosodásnak (MSVI) (V=0,05-0,33) megfeleltethető gyengén látók hazánkban közel hatszor (2011 óta nyolcszor) többen vannak, mint a vakok. Mindennek ellenére az a tapasztalat, hogy hazánkban korántsem ismert a gyengén látás kifejezés pontos jelentése [40].

A legutóbbi népszámlálás (2011) szerint a teljes népességen belül a látáskárosodás prevalenciája $0,83 \%$, a gyermekkori látáskárosodásé pedig $0,026 \%$ volt [34]. Az IABP Vision Atlasban ehhez képest a Magyarországra vonatkozó 2010-es időszakra 14,2\% prevalenciaértéket írtak a látáscsökkent személyek előfordulási arányára, a teljes népességre vonatkoztatva [10]. Szembetûnő, hogy a Vision Atlas nem ugyanazt a felosztást használja, mint a hazai cenzusok. A Vision Atlas a medikális besorolást, míg a hazai népszámlálás $(\mathrm{KSH})$ a fogyatékosság szociális megközelítésư definícióját és fogalmát (látássérült) használja a látáskárosodott személyek meghatározására [23]. A Vision Atlas csakis a látásállapottal összefüggésben gyüjt információkat világszerte, a $\mathrm{KSH}$ látássérültekre vonatkozó népszámlálási adatai pedig csak egy kisebb alkategóriát képviselnek a hazai cenzus- adatok között. A nemzetközi felmérés már 2010-ben differenciálta a távollátásban (distance presenting vision impairment) és a közellátásban (near presenting vision impairment) akadályozott személyek csoportját, továbbá az enyhe fokú látáskárosodás (mild vision impairment) kategóriájába tartozókat is számon tartja. Hazánkban a népszámlálás során nem tettek különbséget a közelre vagy távolra látásban való akadályozottság között, és a visusérték szerint való csoportba sorolás határai sem teljen tisztázottak. Így a hazai népszámlálási adatokban az enyhe fokú látáskárosodás kategóriájába tartozók száma nagy eséllyel csak csekély mértékben látszik. A népszámlálási adatok megbízhatóságát meghatározza az a körülmény is, hogy az adatfelvétel személyi kikérdezésen/önkitöltésen alapul, így a megkérdezettek maguk minősítették saját vagy gyermekük fogyatékosságát. Természetes, hogy az ilyen típusú felvételnél hivatalos kontrollra nincs lehetőség. Ez a módszertani jellegzetesség nyilvánvalóan bizonyos pontatlanságot okoz a fogyatékosok számát és különböző ismérvek szerinti megoszlását illetően [23, 35]. Továbbá azt is figyelembe kell venni, hogy a fogyatékos személyek ismeretei is különösen egyes fogyatékossági típusoknál (például gyengénlátók) - hiányosak lehetnek saját vagy gyermekük fogyatékosságát illetően [23].

Fontos megemlíteni, hogy még a látássérültekkel foglalkozó szakemberek körében is igen gyakran keverednek a látássérülés, látáskárosodás, látásgyengeség, látási fogyatékosság, csökkent látás, gyengén látás fogalmai. Az egyes kifejezések nyilvánvalóan a károsodás mértékének különbségeit igyekeznek megragadni, de rendkívül hasznosnak tartanánk a fogalmak egységes használatának érdekében egy szakmaközi egyeztetést, hogy az aktuális nemzetközi és hazai, továbbá medikális és szociális definíciók közeledjenek egymáshoz. 


\section{A látáskárosodott gyermekek pedagógiai diagnosztikájának kontextusa: az érzékszervi sajátos nevelési igény (látásfogyatékosság) meghatározása}

Hazánkban a látáskárosodott vagy csökkentlátás-gyanús gyermekek ellátási gyakorlatában a gyermekszemészek és a látáskárosodott gyermekek pedagógiai diagnosztikáját végző Látásvizsgáló Gyógypedagógiai Központ között magas szintű együttmúködés alakult ki az elmúlt évtizedek során, különös tekintettel a fővárosban diagnosztizált gyermekek körére. A pedagógiai értelemben vett látássérülés (látásfogyatékosság/érzékszervi sajátos nevelési igény [SNI]) meghatározását a Fővárosi Pedagógiai Szakszolgálat Látásvizsgáló Gyógypedagógiai Tanácsadó, Korai Fejlesztő, Oktató és Gondozó Tagintézménye (röviden: Látásvizsgáló Gyógypedagógiai Központ) végzi. A 2021. január 4-i közlés szerint a Látásvizsgáló Gyógypedagógiai Központ a 7755. számú vizsgálati mappát nyitotta meg az intézmény 1976. évi fennállása óta. A vizsgálatra érkező 0-16 éves gyermekek 85-87\%ban érzékszervi SNI (látásfogyatékos) statust kapnak. Az intézmény országos hatáskörrel bíró pedagógiai szakszolgálatként jogosult arra, hogy 0 és 16 éves kor között hivatalosan differenciálja a látássérülés súlyossági fokának megfelelő kategóriát (vak/gyengén látó), megállapítson társuló fogyatékosságokat, továbbá a szakértői véleménybe foglalt javaslataival hozzásegítse az érintett gyermekeket az állapotuknak és életkoruknak megfelelő sérülésspecifikus pedagógiai ellátáshoz. A pedagógiai túlsúlyú, differenciáló vizsgálatok alapja a szemész szakorvos által megállapított szemészeti diagnózis és visus, amelyet a komplex állapotmegismerésre irányuló pszichológiai és gyógypedagógiai vizsgálatok egészítenek ki [33]. Pedagógiai szempontból csak a látásfogyatékosság gyanúját veti fel a gyógypedagógia gyakorlata a 18 hónap alatti csecsemők és kisgyermekek esetében (15/2013. [II. 26.] EMMI rendelet, 4. \$), amelyet a kora gyermekkori intervenció részeként egy hosszabb fejlesztésorientált megfigyelés során alakít át érzékszervi SNI: látássérülés/látásfogyatékos kategóriává, ha erre az ellátás szempontjából szükség van, vagy szerencsés helyzetben elveti ezt a szülők számára gyakran fájdalmas besorolást. Szemész szakorvosi szempontból ettől még látássérültnek számítanak ezek a gyermekek (például szemüveggel jól korrigálható kancsal vagy túllátó/rövidlátó kisgyermekek), rendszeres szemészeti felülvizsgálataiknak kiemelkedő szerepük van prevenciós szempontból, de látásteljesítményük alapján nem szorulnak speciális pedagógiai eljárásokra. Nyilvánvalóan azok a kisgyermekek, akiknek olyan súlyos fokú a látáskárosodásuk (például anophthalmiával vagy a ROP súlyos fokozatával világra jött csecsemők), hogy egyértelmüen az érzékszervi SNI/látásfogyatékos/vak csoportba sorolhatók, kivételt képeznek az elnyújtott besorolási időszak alól [34]. (Gyógy)pedagógiai értelemben tehát nem minden, szemészeti diagnó- zissal rendelkező gyermek látássérült, de minden, pedagógiai értelemben látássérültnek minősített gyermek rendelkezik olyan szemészeti vagy neurológiai diagnózissal, amely a vizualitását oly mértékben módosítja, hogy az optikai segédeszközzel sem korrigálható annyira, hogy ismeretszerzése, tájékozódása ne korlátozódna jelentősebb mértékben [34].

\section{A látásfogyatékos gyermekek hazai populációjellemzői}

A MÁESZ nyomán 2010 és 2020 között többet tudtunk meg a felnőtt- és időskorú csökkentlátók vagy látáscsökkenéssel veszélyeztett személyek jellemzőiről. A hazai program keretében a gyermekek szürése 2019-ben indult, ennek eredményei egyelőre még nem ismertek. Épp ezért a 0-14 éves, látáskárosodással élő gyermekek egészségügyi és pedagógiai szempontból releváns jellemzőit saját kutatásunk alapján foglaljuk össze [34]. A vizsgálat során adatokat gyújtöttünk a 0-14 éves látáskárosodott gyermekek egészségügyi és pedagógiai jellemzőirôl a Látásvizsgáló Gyógypedagógiai Központ irattárának 2009 és 2013 közötti vizsgálati dokumentációjából. (A vizsgálat részletes eredményeit lásd: Kiss és Pajor, 2020 [34].) Az elemzési mintába azok a 0-14 éves (1995 és 2013 között született) gyermekek adatai kerültek be, akik esetében a szemész szakorvosi és a pedagógiai diagnosztikai folyamat együttesen és egyértelmúen igazolta a látásfogyatékosság (érzékszervi SNI) tényét. Az elemzési minta elemszáma 1432 fó, melynek 31\%-a leány és 69\%-a fiú. A mintában 809 gyermek gyengén látó $(56 \%), 509$ gyermek vak minősítést kapott (36\%), 114 gyermek pedig a besorolás nélküli, 18 hónap alatti csoportba került (8\%), akik kora gyermekkori intervencióra jogosultak a látáscsökkenés gyanúja miatt. A minta életkori terjedelme 2 hónap-14,3 év; az életkori szórás értéke 8,41 év [34].

\section{A látáskárosodás diagnózisának megállapítása}

A szemészeti diagnózisok a gyermekeknek a lakóhelyükhöz rendelt gyermekszemész vagy szemész szakorvosok által kiadott ambulánslapjairól vagy születési, klinikai zárójelentésekről származnak. A látáskárosodás szemészeti diagnosztizálásának ideje alapján két csoportot alkottunk: az iskoláskor előtti időszakot és az iskolásidőszakot. Ez alapján az 1432 gyermek közül 932-en (65\%) hatéves korukig, 500-an (35\%) hatéves koruk után kapták a diagnózist. A szemészeti korrigálhatóság és a korai gyermekrehabilitáció szempontjából igen pozitív, hogy a gyermekeket az esetek felében (50,9\% [467 fö]) már egyéves korukig diagnosztizálták, illetve hogy 262 gyermeknél (18\%) a diagnózist már születéskor rögzítették. 
4. táblázat |A gyengén látás és a vakság fő kórokai gyermekkorban [34]

\begin{tabular}{|c|c|c|c|}
\hline $\begin{array}{l}\text { A gyengén látás } \\
\text { fö okai } \\
\text { (0-14 éves } \\
\text { korban) }\end{array}$ & $\begin{array}{l}\text { Az érintettek } \\
\text { száma és } \\
\text { aránya } \\
(\mathrm{n}=809)\end{array}$ & $\begin{array}{l}\text { A vakság fó okai } \\
\text { (0-14 éves korban) }\end{array}$ & $\begin{array}{l}\text { Az érintettek } \\
\text { száma és } \\
\text { aránya } \\
(\mathrm{n}=509)\end{array}$ \\
\hline Nystagmus & 324 fö (40\%) & ROP & 274 fö (54\%) \\
\hline Strabismus & 308 fó (38\%) & $\begin{array}{l}\text { Kétoldali } \\
\text { látóideg-atrophia }\end{array}$ & 128 fö $(25 \%)$ \\
\hline $\begin{array}{l}\text { Nagyfokú } \\
\text { rövidlátás }\end{array}$ & 286 fó (35\%) & $\begin{array}{l}\text { Nagyfokú } \\
\text { rövidlátás }\end{array}$ & 103 fó (20\%) \\
\hline ROP & 259 fó (32\%) & Glaucoma & 92 fó $(18 \%)$ \\
\hline Amblyopia & 162 fó $(20 \%)$ & Cataracta & 82 fó $(16 \%)$ \\
\hline Hypermetropia & 146 fó (18\%) & Microphthalmia & 79 fó $(16 \%)$ \\
\hline $\begin{array}{l}\text { Kétoldali } \\
\text { látóideg-atrophia }\end{array}$ & 143 fö (17\%) & $\begin{array}{l}\text { Agyi eredetű } \\
\text { látáskárosodás* }\end{array}$ & 79 fó $(16 \%)$ \\
\hline Cataracta & 112 fó $(14 \%)$ & $\begin{array}{l}\text { Coloboma chorioi- } \\
\text { deae et retinae }\end{array}$ & 75 fó $(15 \%)$ \\
\hline
\end{tabular}

*Corpus callosum dysgenesis/agenesis; laesio cerebri progressiva; hydrocephalus; epilepszia

ROP = koraszülöttek ideghártya-károsodása

\section{Szemészeti diagnózisok a vak és a gyengén látó gyermekek körében}

Az elemzési mintában lévő 509 vak és 809 gyengén látó gyermek leggyakrabban elóforduló diagnózisait a 4. táblázat mutatja be [34]. Egy-egy gyermek esetében több szemészeti diagnózis is szerepel a dokumentációban, így a diagnózisok számai nem azonosak az esetszámokkal.

A gyengén látó (MSVI) gyermekek körében a kancsalság és a nagyfokú rövidlátás jelent meg a leggyakoribb kórokként, de igen magas a gyengén látó gyermekek körében a ROP, a tompalátás és a túllátás (hypermetropia) talaján kialakuló látáscsökkenés is. A nystagmus (szemtekerezgés) diagnózisa a gyengén látó gyermekek 40\%-ánál megjelenik. Ez a multifaktoriális kórkép alapvetően neurológiai relevanciájú, látóideg- vagy egyéb centrális sérülésre utal. A vak gyermekek körében maga-

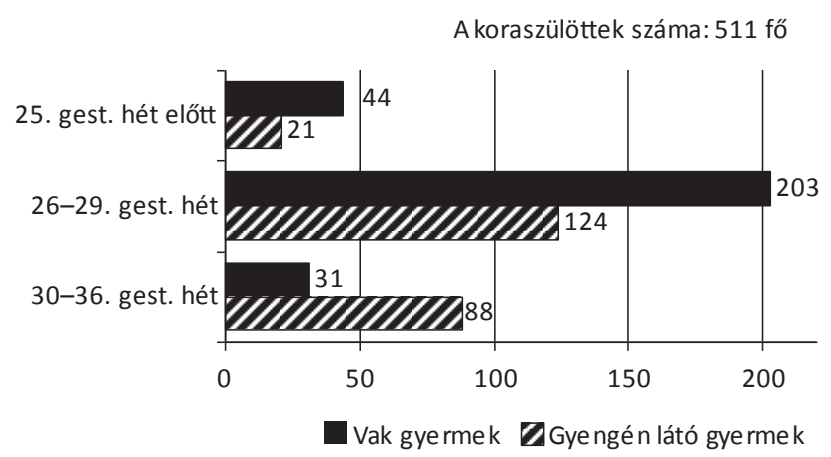

3. ábra

A koraszülöttség előfordulása a vak és a gyengén látó gyermekek csoportjában gestatiós hetekre vonatkoztatva (Kiss és Pajor, 2020) [34] san vezet a koraszülöttség talaján kialakult retinopathia (több mint 50\%), 25\% körüli a látóideg-atrophia és a súlyos fokú rövidlátás. A glaucoma és cataracta előfordulási gyakorisága is inkább a vak gyermekek körében magasabb, mint a gyengénlátóknál. Az agyi eredetû látássérülés csoportba a következő, látássérüléssel összefüggésbe állítható diagnózisok tartoznak: corpus callosum dysgenesis/agenesis, laesio cerebri progressiva, hydrocephalus és epilepszia, Roman-Lantzy [41] nyomán.

\section{Koraszülöttségi jellemzők a vak és gyengén látó gyermekek csoportjában}

A mintában szereplő látássérült gyermekek 35,6\%-a koraszülött volt, közülük a vak gyermekek több mint fele $(54,6 \%)$ érintett, a gyengén látó gyermekeknél ez az arány $28,8 \%$. A 3. ábrán jól látható, hogy a látáskárosodott koraszülött gyermekek többsége a 26-29. gestatiós héten jött világra [34].

\section{Pedagógiai és demográfiai jellemzők}

A vizsgált populáció 44,2\%-ának volt a látásfogyatékosságán túl más fogyatékossága is (autizmusspektrum-zavar; halláskárosodás/mozgáskárosodás; mérsékelt és súlyos fokú intellektuális képességzavar) is: a vak gyermekek körében $55,2 \%$, a gyengénlátóknál $43,6 \%$ a társuló fogyatékosságok előfordulási aránya [34]. A pedagógiai diagnosztikai vizsgálaton megjelenók közül a legtöbb látáskárosodott gyermek Budapestrôl, Pest megyéből és BAZ megyéből érkezik; kevesebben jönnek a dunántúli megyékbő́l, mint a Duna-Tisza közérool és KeletMagyarországról [40]. A pedagógiai diagnosztikai központba korántsem jut el minden csökkentlátó gyermek, ezért a minta nem tekinthetô reprezentatívnak a teljes populációra nézve. Hazánkban azonban nincs még egy olyan specifikus „csúcs”intézmény és adatbázis a látáskárosodott gyermekek vonatkozásában, amely ilyen magas elemszámú és a látáskárosodás meghatározásában megbízható adatokkal rendelkezne, így a vak és gyengén látó gyermekeknek az elemzési mintából nyert csoportjellemzőit jelzésértékűnek és irányadónak tekintjük.

\section{Következtetés}

Az elmúlt 20 év epidemiológiai vizsgálatai igazolták a látásromlás előfordulási gyakoriságának folyamatos emelkedését minden korosztályra kiterjedően. Az évtizedek óta folyó intenzív akcióprogramok ellenére is nő a visszafordíthatatlan látáskárosodással élő személyek száma világszerte, különösen az 50 év felettiek körében. Az elmúlt évek populációalapú, epidemiológiai tanulmányai rávilágítottak arra is, hogy a látásromlás jelentős részének kialakulásában növekszik a korrigálatlan fénytörési hibák szerepe. Riasztóan sokakat, 2,6 milliárd személyt érint világszerte a rövidlátás minden korosztályból, ebből 277 
millió ember él súlyos fokú rövidlátással, és 312 millió személy 19 év alatti. Az emberiség 23\%-a rövidlátó, de a jelenlegi növekedési tendenciák alapján 2050-re az elöfordulás már 50\%-os lehet. A WHO előrejelzései szerint 2050-re 61 millióan élnek majd vaksággal, és 1,7 milliárd személy lehet csökkentlátó világszerte. Kutatások alátámasztják, hogy a látásgyengeség szignifikánsan befolyásolja az életminőséget, megrövidítve a várható élettartamot $[4,5]$.

Mind a nemzetközi, mind pedig a hazai látáskárosodott személyekkel foglalkozó programok átfogóbb és kiterjedtebb szakmaközi összefogást szorgalmaznak a szemgondozás megerősítése érdekében és a megfelelő életminőséget garantáló látás védelmében. A látásvesztésben veszélyeztetett felnőttek és gyermekek megelőző vizsgálatai, szürései elengedhetetlenül fontosak az egészségügyi alapellátásban, ahogyan a 'jó látás’ értékét és ennek megőrzését hangsúlyozó népegészségügyi programok is. Hazánkban ugyan a VISION 2020 mozgalom keretében futó programok széles körü összefogást és közös munkát eredményeztek a vakság és csökkent látás elleni küzdelemben és a látásrehabilitációban, de többségében a látáskárosodással élőkkel foglalkozó társszakmák szakemberei között. Épp ezért fontosnak tartjuk, hogy a program során született eredmények, felismerések - a 'jó látás védelmében' és a 'visszafordíthatatlan látáskárosodással élő személyek komplex rehabilitációja érdekében' - szélesebb körben is elterjedjenek. A prevenció mellett a csökkent/hiányzó vizualitással való életformát támogató szemléletnek és intézkedéseknek (például akadálymentes környezet, a vizuális hiányt tekintetbe vevő kommunikáció) is meg kell jelenniük az egészségügy bármely szektorában, a köznevelésben és a szociális ellátásban egyaránt. Fontos annak tudatosítása, hogy a látásrehabilitáció a jó minőségű ellátás része, és nem az ellátás sikertelenségének jele [4]. A hazai egészségvédelmi szûrőprogramok (MÁESZ 2010-2030) szemészeti vizsgálataiból a felnőtt populáció látásállapotának jellemzőiról és szükségleteirôl már vannak naprakész adataink, azonban a gyermekek szemészeti állapotáról aktuálisan még igen mozaikos a kép. Több mint biztató, hogy a 2020 és 2030 közötti időszakban a gyermekek prevenciójának van kiemelt prioritása a MÁESZ programban.

A látáskárosodás hazai prevalenciája ugyan 45 éves kor felett a legmagasabb, azonban a látásgyengeség bármely formájának prevenciója csak akkor lesz sikeres, ha az intervenció gyermekkorban, sőt kisgyermekkorban elkezdődik. Meglátásunk szerint a siker záloga az interdiszciplináris együttmúködésben és az átláthatóbb, összehangolt betegutak kialakításában rejlik.

Anyagi támogatás: A közlemény megírása anyagi támogatásban nem részesült.
Szerzői munkamegosztás: K. E.: A szakirodalom kutatása, elemzése, az összefoglaló dolgozat megírása, szerkesztése. P. E.: A szakértői feladat ellátása, az irodalomjegyzék véglegesítése, stilisztikai munkák elvégzése. A cikk végleges változatát mindkét szerző elolvasta és jóváhagyta.

Érdekeltségek: A szerzőknek nincsenek érdekeltségeik.

\section{Irodalom}

[1] World Health Organization. World report on vision. WHO, Geneva, 2019. Available from: https://www.who.int/publications-detail-redirect/world-report-on-vision [accessed: December 29, 2020].

[2] Németh J. VISION 2020 in Hungary. [VISION 2020 hazánkban.] Szemészet 2019; 156: 109-118. [Hungarian]

[3] World Health Organization. Blindness and vision impairment. WHO, Geneva, 2020. Available from: https://www.who.int/ news-room/fact-sheets/detail/blindness-and-visual-impairment [accessed: January 10, 2021].

[4] Barcsay Gy, Barcsay VA. Vision rehabilitation services for adults in Hungary. [Látásrehabilitációs lehetőségek felnőtteknek Magyarországon.] Szemészet 2019; 156: 145-147. [Hungarian]

[5] Zeffer T, Szalay L, Deák K, et al. Ophthalmological status and its related life-quality indices in different age groups. [A szemészeti állapot és az életminőség kapcsolódó mérôszámai különböző korcsoportokban.] Orv Hetil. 2020; 161: 1824-1830. [Hungarian]

[6] Thylefors B, Négrel AD, Pararajasegaram R, et al. Global data on blindness. Bull World Health Organ. 1995; 73: 115-121.

[7] World Health Organization. International Classification of Diseases, 11th Revision (ICD-11). WHO, Geneva, 2018. Available from: https://www.who.int/classifications/icd/en/ [accessed: January 10,2021$]$

[8] Steinmetz JD, Bourne RR, Briant PS, et al. Causes of blindness and vision impairment in 2020 and trends over 30 years, and prevalence of avoidable blindness in relation to VISION 2020: the Right to Sight: an analysis for the Global Burden of Disease Study. Lancet Glob Health 2021; 9: el44-el60. [Erratum: Lancet Glob Health 2021; 9: e408.] Available from: https:// www.thelancet.com/pdfs/journals/langlo/PIIS22 14-109X (20)30489-7.pdf [accessed: January 14, 2021].

[9] Bourne RR, Adelson J, Flaxman S, et al. Trends in prevalence of blindness and distance and near vision impairment over 30 years: an analysis for the Global Burden of Disease Study. Lancet Glob Health 2021; 9: el30-e143.

[10] International Agency for the Prevention of Blindness. IAPB Vision Atlas 2020. Country Map \& Estimates of Vision Loss Hungary. Available from: https://www.iapb.org/learn/visionatlas/magnitude-and-projections/country-estimates-of-visionloss/hungary/ [accessed: April 13, 2020].

[11] Bourne RR, Flaxman SR, Braithwaite T, et al. Magnitude, temporal trends, and projections of the global prevalence of blindness and distance and near vision impairment: a systematic review and meta-analysis. Lancet Glob Health 2017; 5: e888-e897.

[12] Fricke TR, Tahhan N, Resnikoff S, et al. Global prevalence of presbyopia and vision impairment from uncorrected presbyopia: systematic review, meta-analysis, and modelling. Ophthalmology 2018; 125: 1492-1499.

[13] Holden BA, Fricke TR, Wilson DA, et al. Global prevalence of myopia and high myopia and temporal trends from 2000 through 2050. Ophthalmology 2016; 123: 1036-1042.

[14] Wong WL, Su X, Li X, et al. Global prevalence of age-related macular degeneration and disease burden projection for 2020 
and 2040: a systematic review and meta-analysis. Lancet Glob Health 2014; 2: el06-ell6.

[15] Ogurtsova K, da Rocha Fernandes JD, Huang Y, et al. IDF Diabetes Atlas: global estimates for the prevalence of diabetes for 2015 and 2040. Diabetes Res Clin Pract. 2017; 128: 40-50.

[16] Tham YC, Li X, Wong TY, et al. Global prevalence of glaucoma and projections of glaucoma burden through 2040: a systematic review and meta-analysis. Ophthalmology 2014; 121: 20812090.

[17] Flaxman SR, Bourne RR, Resnikoff S, et al. Global causes of blindness and distance vision impairment 1990-2020: a systematic review and meta-analysis. Lancet Glob Health 2017; 5: el221-el234

[18] Holland P, Resnikoff S. Beyond VISION 2020: universal eye health coverage and the elimination of trachoma. Commonity Eye Health 2019; 32: 60

[19] Shah SP, Gilbert CE, Razavi HE, et al. Preoperative visual acuity among cataract surgery patients and countries' state of development: a global study. Bull World Health Organ. 2011; 89: 749756.

[20] Németh J, Frigyik A, Vastag O, et al. Causes of blindness in Hungary between 1996 and 2000. [Vaksági okok Magyarországon 1996 és 2000 között.] Szemészet 2005; 142: 127-133. [Hungarian]

[21] Kiss H, Németh J. Causes of blindness in Hungary. [A vakság okai Magyarországon.] Szemészet 2013; 150: 103-111. [Hungarian]

[22] Szabó D, Tóth G, Sándor GL, et al. Causes of blindness in Hungary - conducting the first RAAB study in Hungary. [A vakság okai Magyarországon. A RAAB-metodika első hazai megvalósítása.] Szemészet 2017; 154: 119-125. [Hungarian]

[23] Hungarian Central Statistical Office. Disabled population in Hungary. Methodological notes. In: Janák K, Tokaji K. (eds.) Microcensus 2016, VIII. Characteristics of the population with disabilities and limited health reasons. [Központi Statisztikai Hivatal. Fogyatékos népesség Magyarországon. Módszertani megjegyzések. In: Janák K, Tokaji K. (szerk.) Mikrocenzus 2016. VIII. A fogyatékos és az egészségi ok miatt korlátozott népesség jellemzői.] KSH, Budapest, 2018; pp. 7-10, 29-31. Available from: www.ksh.hu/docs/hun/xftp/idoszaki/mikrocenzus2016/mikrocenzus_2016_8.pdf [accessed: April 13, 2020]. [Hungarian]

[24] Németh J, Maka E, Szabó D, et al. Working telemedicine ophthalmic screening programs and opportunities in Hungary. [Múkködő telemedicinális szemészeti szúróprogramok és lehetőségek hazánkban.] Interdiszciplináris Magyar Egészségügy 2019; 18(8): 46-51.

[25] National Program Committee for Good Vision. [Nemzeti Programbizottság a Jó Látásért.] Available from: http://www.jolatasert.hu [accessed: January 14, 2021]. [Hungarian]

[26] Public Health Prevention in Hungary. Comprehensive health screening program of Hungary 2010-2020-2030. [Népegészségügyi Prevenció Magyarországon. Magyarország átfogó egészségvédelmi szűroóprogramja 2010-2020-2030.] Available from: https://egeszsegprogram.eu/program-tajekoztato [accessed: January 14, 2021]. [Hungarian]

[27] Németh J. 2011-2017 seasons results and presentation of the ophthalmic context. IXth Public Health Conference 2018. [2011-2017. évadok eredmények és a szemészeti összefüggésének bemutatása. IX. Népegészségügyi Konferencia, 2018.] Available from: https://egeszsegprogram.eu/content/kozerdeku-adatok/pdf/szakmai eloadasok/eredmenyek_a_maesz_ program_mukodesebol_(2018)_iv._prof._dr.nemeth_janos.pdf [accessed: January 14, 2021]. [Hungarian]

[28] Németh J. Myopia in Hungary 2014 and 2019 - Prevention. XIth Public Health Conference, 2020 September 10, Budapest. [Rövidlátóság hazánkban 2014 és 2019 évek - Prevenció szükséges. XI. Népegészségügyi Konferencia, Budapest, 2020. szeptember 10.] Available from: https://egeszsegprogram.eu/ content/kozerdeku-adatok/pdf/szakmai eloadasok/eredmenyek_a_maesz_program_mukodesebol_(2020)_xi._prof._dr._ nemeth_janos.pdf [accessed: January 14, 2021]. [Hungarian]

[29] Professional guidelines of the Ministry of Health: Monitoring the visual development of children aged $0-18$ years, on the recognition of squinting and refractive errors. Pediatric ophthalmic screening. [Egészségügyi Minisztérium szakmai irányelve: A 0-18 éves életkorú gyermekek látásfejlődésének követése, a kancsalság és a fénytörési hibák felismeréséről. A gyermekkori szemészeti szûrôvizsgálatok.] Eü Közl. 2009; 21: 3070-3082. [Hungarian]

[30] Professional guidelines of the Ministry of Human Resources for the screening, diagnosis, treatment, and ophthalmic care of retinopathy in preterm infants. [Az Emberi Erőforrások Minisztériuma szakmai irányelve a koraszülöttek retinopathiájának szúréséről, diagnosztikájáról, kezeléséról és szemészeti gondozásáról. Eü Közl. 2016; 2: 293-306.] [Hungarian]

[31] Barna I, Kékes E, Halmy E, et al. Summary Data of Hungary's Comprehensive Health Screening Program (MAESZ) 20102019. [Magyarország átfogó egészségvédelmi szưrőprogramjának (MÁESZ) 2019. évi és 2010-2019 közötti összefoglaló adatai.] LAM 2020; 30: 89-102. Available from: https://egeszsegprogram.eu/gyermek-prevencio-magyarorszagon [accessed: January 14, 2021]. [Hungarian]

[32] Education Office 2020. Guidelines and core programs. Guidelines for the education of students with special educational needs. [Oktatási Hivatal 2020. Irányelvek és alapprogramok. A sajátos nevelési igényű tanulók iskolai oktatásának irányelvei.] Available from: https://www.oktatas.hu/kozneveles/kerettantervek/ 2020_nat/iranyelvek_alapprogramok [accessed: 2 Febr, 2021]. [Hungarian]

[33] Pajor E. Visual impairment - Impaired vision? [Látássérülés Sérült látás?] ELTE Bárczi Gusztáv Gyógypedagógiai Kar, Budapest, 2017. [Hungarian]

[34] Kiss E, Pajor E. The medical and pedagogical features of the population of visually impaired children aged between 0 and 14 in Hungary. [A 0-14 év közötti látássérült gyermekek populációjának egészségügyi és pedagógiai jellemzői Magyarországon.] Szemészet 2020; 157: 294-302. [Hungarian]

[35] Tausz K, Lakatos M. The situation of people with disabilities. [A fogyatékos emberek helyzete.] Stat Szle. 2004; 82: 370-391. [Hungarian]

[36] Hungarian Central Statistical Office 1990. Demographics. In: Nagy O. (ed.) 1990 Census. 27. Demographics, Volume I. [Központi Statisztikai Hivatal 1990. Demográfiai adatok. In: Nagy O. (szerk.) 1990. évi népszámlálás. 27. Demográfiai adatok, I. kötet.] Köponti Statisztikai Hivatal, Budapest, 1993; pp. 33-39, 48-56, 126-135, 257-262. [Hungarian]

[37] Hungarian Central Statistical Office 2011. Retrospective and detailed data on people with disabilities. In: Csordás G. (ed.) 2011 Census, 11. People with disabilities. [Központi Statisztikai Hivatal 2011. A fogyatékossággal élők visszatekintő és részletes adatai. In: Csordás G. (szerk.) 2011 évi népszámlálás, 11. Fogyatékossággal élők.] Köponti Statisztikai Hivatal, Budapest, 2014; pp. 5-78. Available from: www.ksh.hu/docs/hun/xftp/idoszaki/nepsz2011/nepsz_11_2011.pdf [accessed: April 13, 2020]. [Hungarian]

[38] Hungarian Central Statistical Office 2016. Lakatos M. History of Hungarian microcensuses and the 2016 microcensus. In: Németh Zs. (ed.) Microcensus 2016. Topics of the 2016 microcensus. Background studies on the microcensus program and topics. [A magyarországi mikrocenzusok története és a 2016. évi mikrocenzus. In: Németh Zs. (szerk.) Mikrocenzus 2016. A 2016. évi mikrocenzus témakörei. Háttértanulmányok a mikrocenzus programjáról és témaköreirôl.] Köponti Statisztikai Hivatal, Budapest, 2016; pp. 6-44. Available from: www.ksh.hu/ 
docs/hun/xftp/idoszaki/mikrocenzus2016/mikrocenzus_2016_1.pdf [accessed April 13, 2020]. [Hungarian]

[39] Hungarian Central Statistical Office. Census, 2011. [Központi Statisztika Hivatal. Népszámlálás 2011.] Available from: http:// www.nepszamlalas2001.hu/hun/kotetek/kotetek.html (accessed: January 14, 2021]. [Hungarian]

[40] Kiss E. Sociological and mental health aspects of the resources of visually impaired children's parents. In: Gereben F, Cserti-Szauer Cs, et al. (eds.) Special education in dialog. [Látássérült gyermeket nevelő szülőkk erőforrásainak szociológiai és mentálhigiénés megközelítése. In: Gereben F, Cserti-Szauer Cs, et al. (szerk.) Gyógypedagógia - dialógusban.] ELTE Bárczi Gusztáv Gyógypedagógiai Kar, Budapest, 2018; pp. 184-192. [Hungarian]

[41] Roman-Lantzy C. Cortical visual impairment. An approach to assessment and intervention. AFB Press, New York, NY, 2007; pp. 59-64.

(Kiss Erika,

Budapest, Ecseri út 3., 1097 e-mail: kiss.erika@barczi.elte.hu)

\section{„Quam multa, priusque facta sunt, fieri non posse judicantur." (Plinius) (Mennyi mindent tartottak lehetetlennek, mielőtt megtörtént volna.)}

A cikk a Creative Commons Attribution 4.0 International License (https://creativecommons.org/licenses/by/4.0/) feltételei szerint publikált Open Access közlemény, melynek szellemében a cikk bármilyen médiumban szabadon felhasználható, megosztható és újraközölhető, feltéve, hogy az eredeti szerző és a közlés helye, illetve a CC License linkje és az esetlegesen végrehajtott módosítások feltüntetésre kerülnek. (SID_1) 